Чернівці, Україна

\title{
РЕЛІКТИ АПЕЛЯТИВА *VOLJA \\ В СУЧАСНОМУ УКРАЇНСЬКО-ПОЛЬСЬКОМУ ОЙКОНІМНОМУ ПРОСТОРІ
}

Ключові слова: апелятиви (укр. воля, волиия, волька; пол. wola, wolica, wólka), онімізація апелятивів, ойконімія, структурні типи ойконімів

Світлій пам’яті пані професор Барбари Чопек-Копцюх присвячується

\section{1. ВСТУП}

1.1. Мета цієї статті - презентація, класифікація, встановлення продуктивності й поширення сучасних назв поселень із компонентом пол. Wola, Wolica, Wólka укр. Воля, Волиия, Волька, мешканці яких ще в епоху середньовіччя були адміністративно звільнені від податків, або ж самовільно засновували оселі на вільних, незагосподарьованих землях; також маємо на меті вказати на назовничі тенденції, закладені в первинній семантиці базового апелятива *volja та відбиті в його подальшій онімізації в українській та польській ойконімії.

1.2. Тези та гіпотези. Відомо, що будь-яка культура народжується й формується в національних формах. Для того, щоб зрозуміти, що саме і яким чином колись відкривали для себе як давні слов'яни-праслов'янський період, раннє середньовіччя (кінець V ст.-середина XI ст. - Західна Європа, IX-XI ст. - Східна Європа), високе середньовіччя (XI-XIV ст.), пізнє середньовіччя (XIV-XVI ст. - централізація держав під королівською владою), — так і сучасні слов'янські народи, необхідно хоча б у загальних рисах відтворити окремішні картини пізнання ними світу за допомогою словесних образів і понять. Національна своєрідність слов'ян, хоча б 
на прикладі польського та українського народів, виявлялась у словесних образах, у тій «внутрішній формі» слова, яка спочатку виникає в глибокій давнині, а потім при кожному новому називанні поступово хронологічно розгортається в багатстві його переносних значень, які зберігають первинний прадавній словесний образ.

Проте саме в пізньому середньовіччі (XIV-XVI ст.), коли масово почали з'являтися різні населені пункти та залюднюватися території сучасної Польщі та України, в суспільно-економічній, суспільно-політичній та суспільно-господарській термінології предків поляків та українців велику продуктивність отримала лексема воля, яка набула здатності до онімізації, вказуючи на певний тип поселень, звільнених («вільних») від сплати різного виду податків і повинностей, а також - на мешканців, які в них проживали. В українській (східнослов' янській) мові, як і в інших слов'янських (зокрема західнослов' янських, з-поміж яких - польська) мовах, апелятив воля сягає псл. *vol'a (< *vol-ja): польське wola, російське воля, староцерковнослов'янське волга (Boryś, с. 707).

У сучасному ж розумінні семантика лексеми воля в українській мові зводиться до тлумачення: 'відсутність економічного чи політичного гноблення, або ж певних обмежень у суспільно-політичному житті' (СУМ I, с. 735). Воля в своїй основі — це те, що в середньовіччі (далі - у XVII ст. і пізніше - у XVIII, XIX, XX і в теперішньому XXI ст.) вважалося свободою дій, незалежністю: пор. волнағ вола, 1627 р. 'нічим не обмежена свобода' (СУМ XVI-п. пол. XVII ст., с. 223) ${ }^{1}$.

Іншими словами, неможливо зрозуміти та витлумачити давню суспільно-господарську термінологію, зокрема апелятиви на позначення типу поселення, як-от: воля, волька, волиия (або ж близьких до них синонімічних відповідників типу льгота 'пільга', пор.: чеськ. lhota 'пільга', слц. lehota 'т.с.' < псл. *lbgota 'пільга, полегшення' (ЕСУМ 3, с. 345) або слобода (свобода), слобідка 'свобода', пор.: пол. swoboda (świeboda), чеськ. svoboda, слц. sloboda < псл. *svoboda (ЕСУМ 5, с. $198^{2}$ ), не маючи певних уявлень про розвиток понять та образів, скритих у лексемах, які їх закріплювали.

Вважаємо, що ще середньовічна людина в своїх уявленнях намагалася створити певну образно-словесну модель навколишнього світу, тож потреба

\footnotetext{
1 Упродовж свого діахронійного періоду побутування апелятив воля мав досить широке значення: поєднаний у словосполучення «свобода волі» (разом із лексемою свобода) він перейшов у категорію філософської термінології та означає 'можливість вияву певним суб'єктом своєї волі при усвідомленні законів розвитку природи та суспільства'. Треба, однак, зауважити, що з філософського погляду апелятив свобода не виступає синонімом до лексеми воля.

${ }^{2}$ Онімізація праслов' янського апелятива *svoboda та простеження в діахронії його функціонування в ролі назв різного типу поселень у слов'янських країнах, зокрема в Польщі та Україні, буде предметом наших наступних розвідок.
} 
опису ключових понять цієї моделі, одним із яких, без сумніву, було поняття і лексема воля, є особливо актуальною сьогодні. Базову лексему *volja можемо зарахувати до моделі термінів на означення суспільно-господарських стосунків, у яких вона в Україні набула семантичного розвитку ще

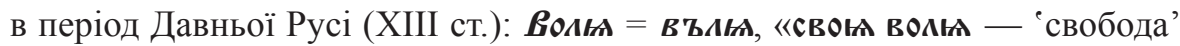

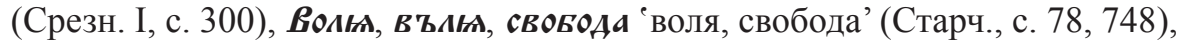
ставши основою для формування назв поселень - українських ойконімів, починаючи із XV ст. (Czapla, 2011, cc. 205-206), пізніше - у XVI-XVIII ст. (Pluskota, 1998), а також (ще давніше) польських - у першій половині XIII ст., де такі номінації вже масово мали місце в XIV та XV ст. (Czopek-Kopciuch, 1988, c. 108).

Особливого значення надаємо онімізації цієї лексеми, в якій розвинулись і за якою потім закріпились поняття та ознаки, на основі яких із предметного світу вичленовуються і оформлюються в слові явища дійсності з потенційною здатністю називати численні «вільні» поселення в Україні (назви поселень типу: Воля, Волиия, Волька та похідні) та Польщі (ойконіми: Wola, Wolica, Wólka та похідні).

Вважаємо, що важливо вказати на онімізацію цієї апелятивної лексеми в українській та польській мовах з ії потенційною здатністю називати різнотипні давні поселення, іншими словами, виступати у функції ойконімів. Тобто - це те, чому в польській мові відповідають лексеми wola, wolnica, wolność із семантикою 'osada, kolonia, zwolniona na pewien czas od podatków, czynszów, pańszczyzn' (SW VII, с. 686), а в українській воля — це 'звільнення селян від кріпацтва' та надання їм можливості створювати «вільні» поселення (СУМ I, с. 735). Адже семантика лексеми воля, за якою пізніше закріпилось ойконімне значення, починалась із усвідомлення висловів: «на волн седетн (осаднтн), посаднти волю, сЊстн на волн», 1552 р., тобто ‘бути звільненим від повинностей і податків; засновувати поселення, жителі якого тимчасово звільнялися від феодальних повинностей і податків', пор.: «посадни соБе волю на Внжвє», 1538 р. (СУМ XVI-п. пол. XVII ст., сс. 223-224). У цих середньовічних словникових дефініціях ми бачимо пряме відбиття розвитку народних уявлень чи образів про соціальні та суспільні відносини цього часового проміжку, які будувалися, якщо говорити про Україну, починаючи ще 3 давньоруського періоду — цілісного та досить важливого компонента в розвитку української культури як культури «середземноморського типу». Встановлено, що протягом усього середньовіччя розмовна руська (українська) мова відчувала помітний вплив з боку католицької культури через посередництво польської мови, адже багато з руських мовних особливостей, які здаються, на перший погляд, питомо своїми, насправді виникли під прямою дією цієї культури (Лавриненко, 2008). 
1.3. Методи. У статті використовуємо лексико-семантичну методику, яка дозволяє встановити тлумачення термінів, зокрема дефініцію лексем wola воля в польських та українських лексикографічних джерелах. Застосовуємо також і елементи статистичного методу, зокрема методику кількісних підрахунків, яка полягає, в нашому випадку, у встановленні кількості ойконімів (як сучасних, так і історичних) на досліджуваній території; беремо до уваги також елементи порівняльно-історичного методу, адже щоб отримати достовірні результати ойконімного характеру, необхідно опиратися на первинні згадки про назви поселень в історичних джерелах (див.: AGZ, Atl. Jabł., MRPS, ЦДІАЛ та ін.).

\section{2. СТАН ДОСЛІДЖЕНЬ}

Сьогодні, треба сказати, активно проводяться дослідження, в яких на основі аналізу джерельного матеріалу активно аналізується найдавніша апелятивна та онімна лексика: це стосується розв'язання проблем, пов'язаних із дослідженням топонімів (зокрема ойконімів) та апелятивів, які лежать в їхній основі.

Так, наприклад, словацький дослідник Рудольф Крайчовіч (Krajčovič, 2005) у монографіï „Živé kroniky slovenských dejín skryté v názvoch obcí a miest» дав визначення номенклатурного терміна vol'a на означення суспільно-господарських стосунків та його відбиття у словацькій ойконімії, вказавши на найбільше географічне поширення на сході Словацької Республіки, на межі з Україною: «[...] na istý čas z vôle zemepána osadníci oslobodení od dávok za užívanie jeho pozemkov [...]. Z apelativa vznikli početné miestne názvy hlavne na východe našej krajiny» (Krajčovič, 2005, c. 210). Найдавніші з такого типу ойконімів, за його спостереженнями, сягають початку XIV ст., з-поміж яких: «Vôl'a, od Michaloviec na severozápad (Wolya, Volya et alia Volya 1337, Volya Zaborsky 1773). - Vyšná Vôl'a, od Bardejova na juhovýchod (Vola 1310, Wissna Wolya 1773). - Nižná Vol'a, od Bardejova na juhovýchod (Vola 1310, Niżna Wolya 1773). — Ruská Vol'a, od Vranova nad Topl’ou na severozápad (Wolya 1356, Ruská Wola 1808). - Juskova Vol'a, od Vranova nad Topl'ou na juhozápad (Volya 1390, Iuskowola 1808, od roku 1927 Juskova Vôl'a)» (Krajčovič, 2005, cc. 210-211).

Ойконім Wola та його похідні потрапляв у поле зору дослідників історичної польської ойконімії періоду I Речі Посполитої. Так, провідна польська ономастка Барбара Чопек-Копцюх (Czopek-Kopciuch, 1988) у монографії «Nazwy miejscowe dawnej ziemi chełmskiej i bełskiej (w granicach dzisiejszego państwa polskiego» на прикладі задекларованих у назві роботи ойконімів Холмської та Белзької земель (у кордонах сучасної держави Польща) періоду 
XV-XVI ст. виявила на цій території з-поміж 2000 назв поселень 88 ойконімів із компонентом Wola, у яких визначила їхню структуру (словоскладання, основоскладання, демінутивація Wola - Wólka та ін.) та констатувала рівномірне поширення на досліджуваній території. Такого типу назви, за спостереженнями дослідниці, є досить характерними для цих земель [Холмської та Белзької] і виражають правничо-господарські стосунки стосовно мешканців нових поселень, звільнених від сплати податків і повинностей (Czopek-Kopciuch, 1988, c. 56).

Тереза Плюскота у монографічному дослідженні «Nazwy miejscowe ziem ruskich Rzeczypospolitej XVI-XVIII w.» (Pluskota, 1998), присвяченому аналізу ойконімії періоду XVI-XVIII ст. історичних руських земель: Белзького, Руського (землі: Холмська, Галицька, Львівська, Перемишльська, Саноцька), Подільського, Волинського (повіти: Луцький, Володимирський, Кременецький), Київського, Брацлавського воєводств, назвам поселень із компонентом Воля та похідними приділяє також певну увагу. Так, за ії̈ спостереженнями, 3-поміж 19000 проаналізованих назв поселень: 1) у Холмській землі таких ойконімів $\epsilon: 16$ назв (для XVI ст.), 9 назв (для XVII ст.), 8 назв (для XVIII ст.); 2) у Галицькій землі: 1 назва (для XVI ст.), 4 назви (для XVII ст.), 1 назва (для XVIII ст.); 3) у Львівській землі: 1 назва (для XVI ст.), 16 назв (для XVII ст.), 3 назви (для XVIII ст.); 4) у Перемишльській землі: 31 назва (для XVI ст.), 7 назв (для XVII ст.), 4 назви (для XVIII ст.); 5) у Луцькому повіті Волинського воєводства: 11 назв (для XVI ст.), 4 (для XVII ст.), 1 назва (для XVIII ст.); 6) у Київському воєводстві: для XVI ст. назви типу Воля відсутні, 2 назви (для XVII ст.), 1 назва (для XVIII ст.); тут спостерігається тенденція до заміни ойконімів типу Воля на ойконіми з компонентом Слобода (Pluskota, cc. 66-67, 92, 117, 142-143, 198-199, 271).

Досліджуючи назви поселень колишньої Львівської землі Руського воєводства, польська дослідниця з Любліна Анна Чапля (Czapla, 2011) 3-поміж 1042 поселень виділяє 14 середньовічних (XV-XVI ст.) ойконімів із компонентом Wola/Wulka (Wólka) у своїй монографії «Nazwy miejsowości historycznej ziemi lwowskiej» (Czapla, 2011, cc. 205-206, 208). Ця ж ономастка, аналізуючи ойконіми (1224 населені пункти) історичної Галицької землі Руського воєводства I Речі Посполитої (цього разу вже в своій габілітаційній монографіï «Nazwy miejscowości historycznej ziemi halickiej» (Czapla, 2018), одним із рецензентів якої був також і автор цієї статті), в історико-етимологічному словнику виокремлює 5 назв поселень із назвами Wola та Wolica iз періоду XVI ст. (Czapla, 2018, сc. 219-220).

Проте можемо вказати тільки на 2 наукові статті (1 польська, 1 українська), безпосередньо присвячені аналізу назв поселень із компонентами Wola Boля: 1) польська дослідниця Геновефа Сурма проаналізувала ойконіми Wola, 
Wólka, Wolica в польській регіональній ойконімії на прикладі Опочинського повіту Лодзького воєводства (Surma, 1996, сc. 51-56); 2) на основі аналізу пам'яток української мови XVI-XVII ст. Р. Осташ простежив функціонування українських ойконімів Воля та Волиия, утворених внаслідок онімізації відповідних апелятивів воля, волиия, та показав вплив народного називання на ïх появу й функціонування. Крім того, автор вказує на часте приєднання до базових компонентів Воля/Волиия атрибутитів для точної локалізації населених пунктів (Осташ, 2007, сс. 222-235).

Отож, наше завдання, як це ми задекларували в меті, полягає у з'ясуванні сучасної продуктивності та поширеності ${ }^{3}$ польських та українських ойконімів із названими компонентами з урахуванням назвотворчих традицій та тенденцій, які збереглися ще з епохи середньовіччя.

\section{3. АНАЛІЗ МАТЕРІАЛУ}

\section{1. Назви поселень із компонентом Воля в сучасній польській ойконімії}

XIII том фундаментальної (та й авторитетної для ономастів і сьогодні) польської енциклопедії кінця XIX століття «Słownik geograficzny Królestwa Polskiego i inych krajów słówiańskich» (далі - SG) містить досить повний реєстр поселень із компонентом воля та, що важливо, дефініцію самого терміна пол. wola: «... nazwa dawana wsiom rolniczym, pojawiającym się już w pierwszej połowie XIII w. i stanowiącym, w stosunku do innych, odrębną kategoryą osad, ze względu na ludność używaną do zasiedlania takowych i nadawane jej swobody» з вказівкою на появу такого типу поселень уже в першій половині XIII ст. на території тогочасного Польського Королівства (SG XIII, c. 774), межі якого охоплювали також і значну територію правобережної України. Отож, дані про населені пункти з компонентом Wola, почерпнуті 3 цього словника, ми розмежовуємо на українські та польські, керуючись логікою їхньої територіальної приналежності в межах сучасних кордонів України та Польщі.

Зроблені нами в SG підрахунки ойконімів на означення поселень, де проживали «вільні» поселенці (ті, котрі були звільнені від усяких повинностей та податків) із компонентом Wola (словосполучення типу: Adj. + Subst.

\footnotetext{
${ }^{3}$ Ми свідомі того, що, вказуючи на географічну поширеність та густоту різних типів ойконімів Wola $\sim$ Воля, варто було би це явище картографувати. Однак значна їхня кількість та й сам обсяг статті, відведений для висвітлення основних ії положень, дозволять це зробити в окремій монографії
} 
Wola/Subst. Wola + Adj.) та 3 кореневим Wol- в однослівних назвах (одноосновні назви-демінутиви: Wolica, Woliczka, Wólka), дозволяють констатувати 1465 онімів, з яких:

1) 809 назв-словосполучень із компонентом пол. Wola $\sim$ укр. Воля (767 польських та 42 українські);

2) 124 назви пол. Wolica; укр. Волиия (46 польських ойконімів та 78 українських);

3) 490 назв пол. Wólka; укр. Волька (440 польських та 50 українських);

4) 15 назв пол. Sucha Wola/Wolica Sucha; укр. Суха Воля/Суха Волиия (11 польських та 4 українських).

5) 3 назви пол. Woliczka = укр. Волька (Воленька) (1 польська та 2 українські)

6) 24 назви - це польські ойконіми типу: Wolaki (3), Wolańczany, Wolańczyce (2), Wolanik, Wolaninowo, Wolaniny-Ratwica, Wolanka (2), Wolanki, Wolanów (2), Wolański Majdan, Wolańszczyzna (2), Wolany (4), Wolarka (2), Wolawce (SG XIII, cc. 774-821). У цій групі ойконімів, які слід вважати секундарними, до певних назв - як-от Wolaki — можуть бути певні застереження щодо їхнього беззаперечного зв'язку із поняттям волі з огляду на багатозначність базової апелятивної лексеми wolak, закладеної в основі назви Wolaki, точніше трьох таких однойменних назв. 3 іншого боку, наявність апелятивів типу wolanin (-anie) 'nowy osadnik na woli, kolonista', wolnik 'nowa osada wyzwolonych chłópów', wolnizna 'stan wolny, wolność', а також прикметника wolny (wolen) 'mający wolność, korzystający z wolności' (SW VII, cc. 686, 688, 691) для інших ойконімів із цього ряду все ж схиляє до думки етимологічно пов'язувати їх із «вільними поселеннями та вільними мешканцями».

У переліку із 176 ойконімів - назви українських населених пунктів, які свого часу входили до складу Речі Посполитолї. Тобто простий підрахунок дозволяє говорити про існування 1289 суто польських ойконімів із компонентом Wola станом на кінець XIX століття.

Знаний польський історик, етнограф та краєзнавець Зигмунт Глогер у своїй «Encyklopedii staropolskiej ilustrowanej» (Warszawa 1903) (далі - ESI) прирівнює у значенні старопольські лексеми wolność та wola, даючи дефініцію останній, як: «... ziemię pustą, oddaną osadnikom z uwolnieniem ich na pewną liczbę lat od wszelkich służb, powinności i czynszów dla dziedzica, nazywano wo lą» (ESI, 1900, c. 471).

Проте статистичні дані поширення ойконімів типу Wola зі «Słownika geograficznego Królestwa Polskiego i inych krajów słówiańskich» (SG XIII), наведені нами вище та подані 3. Глогером в ESI (ESI, 1903), суттєво відрізняються (дивись таблицю). 


\begin{tabular}{|l|c|c|c|c|}
\hline & $\begin{array}{c}\text { Wola } \\
\text { (в тому числі } \\
\text { Sucha Wola) }\end{array}$ & $\begin{array}{c}\text { Wólka } \\
\text { (в тому числі } \\
\text { Woliczka) }\end{array}$ & Wolica & $\begin{array}{c}\text { Інші ойконіми } \\
\text { з коренем } \\
\text { Wol- }\end{array}$ \\
\hline SG & 824 & 493 & 124 & 24 \\
\hline ESI & 301 & 257 & 30 & 5 \\
\hline
\end{tabular}

Неточність даних, як показує порівняння, полягає в тому, що за 10 років, які минули в проміжку від часу появи тринадцятого тому SG (1893р.) та видання ESI (1903р.) кількість населених пунктів, а відповідно і їхніх назв, не могла так суттєво зменшитися: на 523 (824 - 301) — для ойконімів типу Воля); на 436 (для ойконімів типу Wólka (Woliczka) (493 - 57); на 94 (124 $30)$ - для ойконімів типу Wolica. Тут схиляємось до авторитетності SG, яка $\epsilon$ поза всяким сумнівом, як і достовірність та обсяг даних, вміщених саме в ньому (на противагу, однак, ESI).

Зрештою, доречною видається думка згаданої нами Геновефи Сурми, яка, цитуючи А. Брюкнера та Г. Борка, посилається на середньовічні джерела, вказуючи на поширеність назв Wola та Wólka в XVI ст. у Малопольщі (444 назви), Мазовші (134 назви) з найбільшою продуктивністю (до 1000 назв) у колишній Речі Посполитій. У самому ж Опочинському повіті, ойконіми якого були об'єктом іiі аналізу, у минулому нараховувалось понад 90 назв цього типу, з яких збереглося до сьогодні 40 (Surma, 1996, с. 51).

На основі аналізу сучасних адміністративно-територіальних джерел ми встановили кількість та поширення ойконімів із цими компонентами станом на 2021 рік на території всієї Польщі, погрупувавши їх за структурою.

Так, загальна кількість однослівних назв поселень типу Wola (назви окремих сіл та їх частин) становить 53 (див.: «Wykaz urzędowych nazw miejscowości i ich części 2019», далі — Wykaz 2019). Із компонентом Wola в сучасній ойконімії Польщі сьогодні виокремлюємо 788 онімів-словосполучень, які можна розподілити на два типи: 1 . Adj. + Subst. Wola (329 назв). Цікавою тут видається однойменна назва поселень типу Boża Wola, яка зустрічається аж 14 разів (5 назв у Мазовецькому воєводстві, по 2 в Люблінському та Прикарпатському, по одній - у Лодзькому, Свєнтокжиському, Великопольському та ВармінськоМазурському) та має, як вважаємо, культовий характер; 2. Subst. Wola + Adj. (459 назв). У цих ад'єктивно-субстантивних чи субстантивно-ад'єктивних словосполученнях означальний компонент вказує або на колишню первинну приналежість поселення до якогось власника (Mrozowa Wola, Wola Weżykowa, Wola Matiaszowa), або ж на його топографічне місцерозташування (розміри, уточнення локалізації щодо іншого поселення: Dzierzkowice-Wola, Wola 
Uchańska, Wola Lagiewnicka) при базовому компонентові Wola, який указує на тип оселі. Якщо взяти до уваги територіальне поширення таких назв, то сьогодні найбільша їхня кількість сконцентрована в південно-східній частині Польщі (Малопольща), центрально-східній іiі частині (Мазовше); натомість на півночі Польщі (Помор’ї) та у центрально-західній частині (Великопольщі) назви цього типу практично відсутні.

Загальне число однослівних ойконімів Wólka становить 64 - це назви як окремих сіл, так і їхніх частин (Wykaz 2019), і зосереджені вони здебільшого на південному сході, сході та півдні Польщі, а саме: в Люблінському, Підкарпатському та Сілезькому воєводствах. Північно-центральні (КуявськоПоморське воєводство), північно-східні (Підляське воєводство) та центральні (Мазовецьке, Лодзьке воєводства) частини держави такими назвами представлені значно менше.

Словоскладання (складні ойконіми) із препозитивним ад'єктивним компонентом і постпозитивним компонентом -wola (-wólka) та сполучним голосним $o$ становлять 77 назв, 3-поміж яких можна виокремити 4 характерних типи однойменних назв (21 ойконім), як-от: 1) Suchowola (12 ойконімів: 6 - у Люблінському воєводстві; по 1 - у Лодзькому, Мазовецькому, Підкарпатському та Підляському; 3 - у Сьвєнтокжиському); 2) Dobrowola (4 ойконіми: 3 - у Люблінському, 1 - у Західнопоморському воєводствах); 3) Górnowola (Majoratna, Szpitalna) (3 ойконіми у Сьвєнтокжиському воєводстві); 4) Krzywowólka (3 ойконіми: 2 - у Люблінському, 1 - у Підляському воєводстві).

Знову ж таки, ад'єктивно-субстантивні чи субстантивно-ад'єктивні словосполучення з компонентом Wólka (591 назва), як і подані вище назви-словосполучення з базовим Wola, також утворюють однотипні структурні моделі (Wykaz, 2019): 1. Adj. + Subst. Wólka (255 назв), напр.: Boża Wólka, Cicha Wólka, Duża Wólka; 2. Subst. Wólka + Adj (336 назв), напр.: Wólka Abramowicka, Wólka Kątna, Wólka Zychowa.

Однослівних назв населених пунктів типу Wolica нараховуємо 30, а словосполучень (Subst. Wolica + Adj.), у яких другим компонентом виступає означення, - 14; всього зустрічається 2 назви Wolice у формі pluralia tantum (Wykaz 2019).

Загальна ж кількість ойконімів із компонентом Wola, Wolica та Wólka сьогодні в Польщі складає 1542 назви. Із семантичного погляду назви поселень у представлених структурних типах або вказують на локалізацію поселення стосовно іншого (включно з розмірами, віком), або - на колишнього власника-засновника (відантропонімні), напр.: Wólka Bielińska, KrasowoWólka, Nowa Wólka, Wólka Czarnińska, Wólka Duża. Тобто ойконіми тут чітко 
виконують свою диференціюючу та ідентифікуючу функцію. Компоненти назв Wola, Wolica (Wólka) незалежно від структури вживаються паралельно: Wola $=$ Wolica $=$ Wólka (пор.: Wola Stopska $=$ Stopska Wólka (NMPol XIV, c. 132).

Підсумовуючи сказане про географічну локалізацію назв із компонентом wola в польській ойконімії, можна стверджувати, що рівномірне їхнє поширення спостерігається в Люблінському, Малопольському, Підкарпатському воєводствах, а також, додамо, на території історичного Мазовша (суч. Мазовецьке воєводство), на що справедливо вказує польська дослідниця Уршуля Біяк в одному зі своїх останніх досліджень, присвяченому аналізу природного і культурного ландшафту з точки зору історичної географії та їхнього відображення в польській топонімії, що вносить корективи в наші висновки таз чим ми погоджуємося (Bijak, 2021, cc. 201-202, карта 3).

\section{2. Назви поселень із компонентом Воля в сучасній українській} ойконімії

Розглянемо українські ойконіми із компонентом воля, виходячи із його середньовічного значення (XV-XVI ст.), яке поширилося на назви сіл і в п. пол. XVII ст., як поселення, засноване на «суворому корінні», тобто на необробленому грунті, із застосуванням для його нових жителів, волян, пільг для загосподарювання. Адже волғнє, 1637 р. — це 'селяни, які поселились на вільних землях або тимчасово звільнені від феодальних повинностей' (СУМ XVI-П. пол. XVII ст., с. 224), тобто ті, що на Воли передместской и на весце мешкають, 1649 р. (АЮЗР 3/IV, сc. 156-157).

Власне такі численні вільні поселення - Волі (інша назва: слободи, слобidкu) - почали з'являтися на території України в староукраїнський період, починаючи ще з: 1) XIV ст.: волғ 'слобода', XIV-XV ст. (Тимченко I, с. 306307); 2) XV ст.: волг, волА, вол' ' 'тимчасове звільнення новосельців від феодальних повинностей і податків', XV ст. (ССУМ I, сс. 195-196); 3) XVI ст.: до волн, вола, 1546 р. '6. (поселення людей, яких на певний термін звільняли від повинностей і податків) воля, свобода' (СУМ XVI-п.пол. XVII ст., с. 223).

Як і польські НП з онімізованим компонентом wola, українські ойконіми, починаючи з XV ст., створювали різноструктурні типи, які збереглися до сьогодні. Такою є назва неіснуючого поселення *Воля Щирещька. Сьогодні це присілок селища міського типу Щирець Пустомитівського р-ну, Лв. (АТУ, 2012, с. 223), на що вказував польський історик права Пшемислав Домбковські: «Szczerzecka Wola (nad rz. Szczercem), zlała się z m. Szczercem» (Dąbkowski, 1939, с. 84). Саму ж назву Щиреиька Воля, як досить давню, засвідчено 1407 року: Wola Szczerzecka (ad Szczerzec) (AGZ II, c. 35, 59). Назва 
носить локативно-антропогенний характер, містячи вказівку на місцерозташування поселення (ад’єктивний компонент Щирецька) та вказуючи на його тип — воля «звільнення селян від кріпацтва» (СУМ I, с. 735). Щирецька Воля було тим НП, де проживали звільнені від феодальних податей мешканці. Зрештою найбільша кількість українських ойконімів із компонентом воля засвідчена історичними джерелами в XVI ст. (пор.: Волга, 1585 р.; Грушоваг

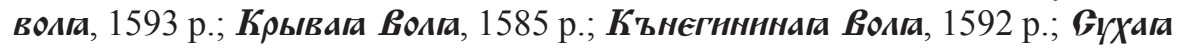

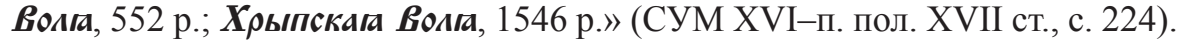

Сам термін воля як «поселення людей, яких на деякий час звільняли від повинностей і сплати податків» мав свої синонімічні відповідники, як-от: апел. волька (волиия), вулька волька, волка 'поселення, мешканці якого на певний час були звільнені від повинностей, податків'; «на вольце нашой Девлннской», 1591 р.; «... на волце новоосажоной», 1649 р. (СУМ ХVI-П. пол. XVII, 4, с. 218); вулька «назва зменшена від воля», означає оселю, закладену на окремих вольностях, свободах» (Крип'якевич, 2009, с. 92). Стосовно лексеми вулька, то тут, швидше, спостерігається рефлекс середньопольського $o ́$ (wólka, wulka) з його переходом в $y$ (вулька) у західноукраїнських діалектах.

У назвах поселень зі складовими компонентами Воля $\sim$ Волиця, Волька базові апелятиви воля волиия, волька є абсолютними синонімами, що підтверджують джерельні записи: «Wola Dobrostańska alias [укр.: інакше, по-іншому] Wolica» (Lustr. 1661-1665/II, с. 193). Крім того, воля, волиия та волька не $\epsilon$ демінутивами до воля, іншими словами, поселення, ними названі, $є$ однаковими за розміром. Про градацію розмірів НП, які здебільшого виступають суміжними, свідчать означальні диференціюючі компоненти назв велик(- $a)$ ий та мал(-а)ий: пор.: Велика Воля (Лв)/Мала Воля (Лв)/Велика Волиия (Жт). У середньовічних латиномовних документах ці назви кваліфікуються як: «Volia utraque Maior et Minor», 1497 p. (MRPS II, cc. 44, 46).

Загальну ж кількість сучасних українських ойконімів із компонентами Воля, Волиия можна розподілити на такі структурні типи або ж моделі:

1. Однослівні ойконіми Воля (загалом 9 назв):

Вл, Днц, Лв (2), Мк (3), Пл, Тр (АТУ, 2012, сс. 53, 97, 227, 230, 239, 240, 272, 323; «Алфавітний покажчик населених пунктів України» (далі - АП $\left.2021^{4}\right)$.

Словоскладання із препозитивним ад'єктивним компонентом і постпозитивним компонентом -воля (-волиия) (загалом 15 назв):

Самоволя (Вл) (АТУ, 2012, с. 50), Красноволя (3) (Вл) (АТУ, 2012, сс. 52, 55), Красноволиия (ЖТ) (АТУ, 2012, с. 118), Суховоля (Вл) (АТУ, 2012, с. 54), Суховоля (2) (ЖТ) (АТУ, 2012, сс. 106, 112), Суховоля (3) (Лв) (АТУ,

\footnotetext{
${ }^{4}$ http://static.rada.gov.ua/zakon/new/NEWSAIT/ADM/zmist.html (доступ 22.02.2021)
} 
2012, сс. 214, 216, 227), Суховоля (Рв) (АТУ, 2012, с. 285), Купичволя (Лв) (АТУ, 2012, с. 218), Довговоля (Рв) (АТУ, 2012, с. 285), Мокроволя (Хм) (АТУ, 2012, c. 363; АП 2021)

2. Adj. + Subst. Воля (загалом 21 ойконім):

Арламівська Воля (Лв) (АТУ, 2012, с. 221), Березна Воля (Вл) (АТУ, 2012, с. 54), Більська Воля (Рв) (АТУ, 2012, с. 285), Божа Воля (Лв) (АТУ, 2012, с. 230), Велика Воля (Лв) (АТУ, 2012, с. 221), Галина Воля (Вл) (АТУ, 2012, с. 57), Добра Воля (Мк) (АТУ, 2012, с. 241), Красна Воля (Днп) (АТУ, 2012, с. 72), Кухітська Воля (Рв) (АТУ, 2012, с. 288), Любешівська Воля (Вл) (АТУ, 2012, с. 54), Майстрова Воля (ЖТ) (АТУ, 2012, с. 112), Мала Воля (Лв) (АТУ, 2012, с. 221), Малнівська Воля (Лв) (АТУ, 2012, с. 222), Марія-Воля (Вл) (АТУ, 2012, с. 49), Маркова Воля (Жт) (АТУ, 2012, с. 115), Нова Воля (Вл) (АТУ, 2012, с. 57), Писарева Воля (Вл) (АТУ, 2012, с. 49), Червона Воля (ЖТ) (АТУ, 2012, с. 113), Черемошна Воля (Вл) (АТУ, 2012, с. 55), Чорнокінеиька Воля (Тр) (АТУ, 2012, с. 325), Щитинська Воля (Вл) (АТУ, 2012, с. 56; АП 2021 доступ 23.02.2021).

3. Subst. Воля + Adj. (загалом 17 назв населених пунктів):

Воля-Баранецька (Лв) (АТУ, 2012, с. 225), Воля-Бартатівська (Лв) (АТУ, 2012, с. 215), Воля-Блажівська (Лв) (АТУ, 2012, с. 225), Воля-Висоџька (Лв) (АТУ, 2012, с. 218), Воля-Гомулецька (Лв) (АТУ, 2012, с. 218), Воля-Добростанська (Лв) (АТУ, 2012, с. 230), Воля-Довголуиька (Лв) (АТУ, 2012, с. 228), Воля-Задереваџька (Лв) (АТУ, 2012, с. 228), Воля-Жовтанеиька (Лв) (АТУ, 2012, с. 220), Воля-Ковельська (Вл) (АТУ, 2012, с. 52), Воля Любинська (Лв) (АТУ, 2012, с. 230), Воля-Любитівська (Вл) (АТУ, 2012, с. 52), Воля-Облазницька (Лв) (АТУ, 2012, с. 218), Воля-Садківська (Лв) (АТУ, 2012, с. 222), Воля-Свійчівська (Вл) (АТУ, 2012, с. 49), Воля-Старицька (Лв) (АТУ, 2012, с. 230), Воля Якубова (Лв) (АТУ, 2012, с. 216; АП 2021; доступ 25.02.2021).

4. Волиия (23 назви поселень):

Вл (3); Жт (2); Кв (2); Лв (7); Рв; Тр (5); Хм (4) (АТУ, 2012, сc. 50, 51, 58, 103, 108, 166, 176, 218, 221, 222, 224, 225, 226, 290, 315, 317, 320, 321, 323, 369, 371, 374; АП 2021).

5. Subst. Волиия + Adj. (9 ойконімів):

Воличя-Барилова (Лв) (АТУ, 2012, с. 224), Волиия-Гніздичівська (Лв) (АТУ, 2012, с. 217), Волиия-Деревлянська (Лв) (АТУ, 2012, с. 215), Волиия Друга (Хм) (АТУ, 2012, с. 369), Волиия-Дружкопільська (Вл) (АТУ, 2012, с. 49), Волиия-Керекешина (Хм) (АТУ, 2012, с. 372), Волиия-Лобачівська (Вл) (АТУ, 2012, с. 49), Волищя-Морозовищька (Вл) (АТУ, 2012, с. 51), Волищя-Польова (Хм) (АТУ, 2012, с. 373; АП 2021; доступ 26.02.2021). 
6. Adj. + Subst. Волиия, Волька (1 ойконім):

Лісова Волиия (Хм) (АТУ, 2012, с. 369; АП 2021; доступ 27.02.2021).

Підрахувавши загальну кількість назв українських назв населених пунктів із компонентом воля отримаємо число 95, і всі вони географічно майже компактно розташовані на заході України: Львівська (38) та Волинська (23) області, а також - Хмельницька (9), Тернопільська (7), Ровенська (5) області. Таку значну кількість ойконімів у Західній Україні пояснюємо середньовічними колонізаційними поселенськими процесами, які відбулися на цих землях (колишні Белзьке, Руське, Подільське, Волинське воєводства Речі Посполитої) у пізньому середньовіччі (поч. XIV-XVI ст.).

Решта ж назв $є$ нечисленною і має поширення: у центрі України - це Житомирська (8), Кіровоградська (3), Полтавська (1), на південному сході Миколаївська (4), на сході - Донецька (1), Дніпропетровська (1). Треба сказати, що масові поселенські процеси у центрі, на сході та на південному сході України мали місце значно пізніше, починаючи десь із XVIII століття.

Багато назв давніх українських поселень у радянські часи були перейменовані, що негативно позначилося на збереженні історичної інформації про їхне заснування. 3 граматичного погляду такі ойконіми часто зазнавали універбації (семантичної компресії). Так, назву села Воля Задеревацька (Стрийський р-н, Лв), відомого із XVI ст. як Wola Zaderewacka (Atl. Jabł., карта 3), було перейменовано на Задеревиі, а село Воля Якубова того ж району та області - на Воля. I тільки в 1992 році вдалося відновити первинну історичну назву: на державному рівні зробити офіційне перейменування, тобто повернути цим населеним пунктам їхні старі назви Воля Задеревацька та Воля Якубова (ВідВРУ, 03.03.1992, №9, с. 251; АТУ, 2012, с. 558). Ідеологічного забарвлення в радянські часи зазнала також назва поселення Божа Воля (Яворівський р-н, Лв.), перейменованого в Червона Воля, пор.: Червона Воля - назва села у Новоград-Волинському районі, Жт (АТУ, 2012, с. 113), в якій означальний компонент «червона» мав указувати на один із радянських символів (пор. інші радянські перейменування цього типу: Червона Зоря, Червона Нива, Червона Перемога та ін.). У тому ж 1992 році було відновлено, тобто документально засвідчено перейменування Божа Воля (АТУ, 2012, с. 556; ВідВРУ, 03.03.1992, №9, сс. 253-254). Перейменувальні процеси, які торкнулися назв із компонентом Воля мають ще й уточнювальний характер: так, орфографічно було поправлено назву населеного пункту Малнівська Воля (Мостиський р-н, Лв) із помилкового запису в означальному компоненті, поданого як Мальнівська Воля (АТУ, 2012, с. 705; ВідВРУ, 20.04.1993, №16, с. 431).

3 одного боку, згадані вище перейменування свідчать про тенденцію до відновлення первинних історичних назв, зокрема з аналізованим нами 
компонентом Воля, а їхня кількість — 95 назв населених пунктів — чітко відповідає існуючим сьогодні поселенським об'єктам цього типу.

3 іншого ж боку, такі назви могли зникати природнім шляхом. Так, наприклад, неіснуюче сьогодні поселення *Воля-Замарстинівська, вперше згадане в історичних документах у 1570 році як Wolica: «[...] osadzili ususzywszy błoto [...] y nazwali to wsią Wolica» (ЦДІАЛ. Фонд 52, опис 1, справа 391, аркуш 26-27), розташовувалось на міських ланах міста Львова (як і сам зниклий НП *Замарстинів, який був розташований на околиці міста Львова, ввійшовши пізніше до його складу).

\section{4. ВИСНОВКИ}

Історія становлення апелятивів укр. воля та пол. wola подана нами із врахуванням загального фону соціальної (суспільно-господарської, суспільно-економічної, суспільно-політичної) термінології середньовіччя, яка зробила помітний вплив на формування уявлень і понять як поляків, так і українців при називанні поселень різного типу.

Поява ойконімів із компонентом Wola, Wólka, Wolica $~$ Воля, Волиия, Волька є результатом середньовічних поселенських процесів, які проходили на території Польщі (Люблінське, Підкарпатське, Малопольське, Мазовецьке воєводства) та західної України (Львівська, Волинська, Хмельницька, Тернопільська області), починаючи з XIV ст.-XVI ст., маючи місце в XVII-XVIII, XIX, XX ст. та до наших днів.

Як засвідчили дані з «Wykazu urzędowych nazw miejscowości i ich części 2019» та «Алфавітного покажчика населених пунктів України 2021», ойконіми із компонентами Wola $\sim$ Воля впродовж своєї еволюції сформували майже однакові структурні типи, які збереглися донині в польській та українській ойконімії. Зокрема це: однослівні ойконіми; словоскладання із препозитивним означальним компонентом і постпозитивним компонентом -воля (-волиия); оніми-словосполучення: 1. Adj. + Subst. Wola, Wolica, Wólka Воля, Волиия, Волька; 2. Subst. Wola, Wolica, Wólka Воля, Волиия, Волька + Adj. Найбільшою продуктивністю відзначаються відтопонімічні (локалізуюча функція поселення в просторі та місцерозташування НП один відносно іншого) і відприсвійні словосполучення (присвійний член назви походить від скорочених та повних імен, від прізвищ або прізвиськ власників чи засновників), щоби назва могла виконувати свою диференціюючу та ідентифікуючу функції.

Між компонентами словосполучень можна визначити наступні відношення: ад'єктивний компонент має топографічний (відойконімний) характер: Wola Łagiewnicka, Wola Wereszczyńska, Zakrzewska Wola Воля-Добростанська, 
Чорнокінецька Воля, а також пов'язаний із фізіогеографічними реаліями ландшафту: Wola Sosnowa, Wola Wakopna Волиия-Польова, Мокроволя; означуваний компонент має присвійний характер (вказівка на власника, засновника): Wola Aleksandra, Bobrowa Wola, Wola Matiaszowa Волиия Барилова, Галина Воля, Маркова Воля; відношення між даним об'єктом та іншим об'єктом 3 метою локалізації села, опису його ландшафтного розташування (близьке сусідство, ближні й дальні околиці): Podleśna Wola, Podmiejska Wola Лicoвa Воля, Волиия Друга; вказівка на вік поселення: Wolica Nowa, Wolica Stara Воля (як опозиційна пара - Cтара), Нова Воля; вказівка на розмір поселення: Wielka Wola, Wola Mała Велика Воля, Мала Воля.

Якщо статистично порівняти кількість ойконімів із компонентами Wola, Wolica, Wólka Воля, Волиия, Волька, які до сьогодні збереглися в Польщі та Україні, то згідно $з$ даними «Wykazu 2019» та «АП 2021», можна констатувати наступне: 1) у Польщі - це 1542 назви; 2) в Україні - 95 назв. Крім того, дані, подані нами вище із «Słownika geograficznego...», вказують, що із загальної кількості назв (1465 ойконімів) Польського Королівства на українські припадає 176 назв поселень. Відповідно 1289 онімів - це питомо польські ойконіми.

Логіка підрахунків, зроблених на підставі цих трьох джерел, підказує, що, починаючи з кінця XIX ст. і до сьогодні, в Польщі їхня кількість зросла на 253 одиниці, а в Україні - зменшилася на 81 (176 - 95).

Можлива дискусійність висновків на основі цих даних полягає в тому, що така значна кількість польських назв пояснюється тим, що сучасний «Wykaz 2019» враховує не тільки окремі села з компонентом Wola, але й їхні частини (пол. część wsi, kolonii), на відміну від українського «АП 2021», який, навпаки, містить тільки назви сіл із компонентом Воля.

Така значна кількість польських та українських ойконімів типу Wola Воля, порівняно з іншими назвами поселень, свідчить також не тільки про адміністративно-правове надання окремим суспільним верствам певних вольностей і свобод, але й часто — про стихійне, спонтанне заснування групами середньовічних колонізаторів «вільних» поселень на незаселених територіях. 3 хронологічного погляду не можна простежити якоїсь законо-

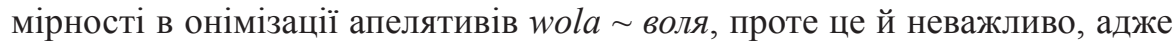
майже всі ойконіми цього типу виникли в період середньовіччя та засвідчують у своїх назвах тогочасне прагнення суспільних верств до «вільного життя», «життя на волі».

Сформована у назвах поселень із компонентом Wola $\sim$ Воля культура номінаційних процесів, як вважаємо, справила важливий вплив на становлення онімних систем Польщі та України в наступні століття. У перспективі доречним видається аналіз семантично спорідненої до wola $\sim$ воля лексеми 
swoboda (świboda, swyboda) cвободa, враховуючи потенційну здатність останньої до номінації поселень, що дасть можливість встановити сучасну продуктивність, географічну локалізацію та семантичний рух такого типу термінів на позначення суспільно-господарських стосунків в українських та польських ойконімах.

\section{ПРИЙНЯТІ СКОРОЧЕННЯ}

$<$ - походить від

Вл - Волинська

див. - дивись

Днп - Дніпропетровська

др. пол. - друга половина

Жт - Житомирська

Кв - Кіровоградська

Мк - Миколаївська

НП — населений пункт

Од - Одеська

п. пол. — перша половина

Пл - Полтавська

пол. - польське

поч. - початок

псл. — праслов'янське

р. - рік

Рв - Ровенська

p-н - район

c. - сторінка

слц. - словацьке

сс. - сторінки

ст. - століття

суч. - сучасне

Тр - Тернопільська

укр. - українське

Хм - Хмельницька

чеськ. - чеське

Чрн - Чернівецька

\section{ЛІТЕРАТУРА ТА ДЖЕРЕЛА}

AGZ = Tatomir, L., Liske, K. i Prochaska, A. (red.). (1868-1935). Akta grodzkie i ziemskie z czasów Rzeczypospolitej Polskiej z Archiwum tak zwanego Bernardyńskiego we Lwowie (t. 1-25). Lwów: w drukarni Zakładu im. Ossolińskich.

Atl. Jabł. = Jabłonowski, A. (red.). (1889-1904). Atlas historyczny Rzeczypospolitej Polskiej. Epoka przełomu z wieku XVI na XVII. Dział II: Ziemie Ruskie Rzeczypospolitej. Warszawa-Wiedeń: C. i K. Wojskowo-Geograficzny Zakład w Wiedniu. 
Bijak, U. (2021). Space and landscape in Polish toponymy. Jazykovedný časopis (Journal of Linguistics), 72(1), 194-207.

Boryś, W. (2005). Słownik etymologiczny języka polskiego. Kraków: Wydawnictwo Literackie. Czapla, A. (2018). Nazwy miejscowości historycznej ziemi halickiej. Lublin: Wydawnictwo KUL.

Czapla, A. (2011). Nazwy miejscowości historycznej ziemi lwowskiej. Lublin: Towarzystwo Naukowe KUL.

Czopek-Kopciuch, B. (1988). Nazwy miejscowe dawnej ziemi chetmskiej i betskiej (w granicach dzisiejszego państwa polskiego. Wrocław: Zakład Narodowy im. Ossolińskich.

Dąbkowski, P. (1939). Podział administracyjny województwa Ruskiego i Bełskiego w XV wieku (z mapą) W: Zabytki dziejowe (t. 5). Lwów: Towarzystwo Naukowe.

ESI = Gloger, Z. (1903). Encyklopedia staropolska ilustrowana (t. 4). Warszawa: Druk P. Laskauera i W. Babickiego.

Krajčovič, R. (2005). Živé kroniky slovenských dejín skryté v názvoch obcí a miest. Bratislava: Literárne informačné centrum.

Lustr. 1661-1665/II - Arłamowscy E. i K. (red.). (1974). Lustracja województwa ruskiego 16611665. Część II: Ziemia Lwowska. Wrocław: Zakład Narodowy im. Ossolińskich.

MRPS = Wierzbowski T. (red.). (1905-1910). Matricularum Regni Poloniae Summaria (t. 1-4). Varsoviae: Typis officinae C. Kowalewski.

NMPol = Rymut, K. i in. (red.). (1996-2018). Nazwy miejscowe Polski. Historia. Pochodzenie. Zmiany (t. 1-15). Kraków: Instytut Języka Polskiego PAN.

Pluskota, T. (1998). Nazwy miejscowe ziem ruskich Rzeczypospolitej XVI-XVIII w. Bydgoszcz: Wydawnictwo Uczelniane WSP w Bydgoszczy.

SG = Sulimierski T. i in. (red.). (1880-1902) Stownik geograficzny Królestwa Polskiego i innych krajów słowiańskich (t. 1-15). Warszawa: Nakładem Filipa Sulimierskiego i Władysława Walewskiego. Druk, „Wieku”.

Surma, G. (1996). Nazwy miejscowe z członem Wola, Wólka, Wolica w procesie komunikacji językowej (na przykładzie Opoczyńskiego). Onomastica, 41, 51-56.

SW = Karłowicz J. i in. (red.). (1900-1927). Słownik języka polskiego (t. 1-8). Warszawa: Nakładem prenumeratorów w drukarni E. Lubowskiego i S-ki.

Wykaz 2019 = Wykaz urzędowych nazw miejscowości i ich części (2019). http://ksng.gugik.gov.pl/ urzedowe_nazwy_miejscowosci.php (доступ 21-25.02.2021).

АП 2021 = Алфавітний покажчик населених пунктів України. http:/static.rada.gov.ua/zakon/ new/NEWSAIT/ADM/zmist.html (доступ 21-27.02.2021).

АТУ, 2012 = Скопненко, Г.П. (red.). (2012). Україна: Адміністративно-територіальний устрій (станом на 1 січня 2012 р.). Київ: Парламентське видавництво.

АЮЗР (1859-1914) = Архив Юго-Западной России, издаваемый Временною комиссиею для разбора древних актов высочайше учрежденною при Киевском, Подольском и Волынском генерал-губернаторе (Ч. 1-8. Т. 1-35). Киевъ: Въ университетской типографіи.

ВідВРУ (03.03.1992, №9, s. 251; ВідВРУ, 03.03.1992, №9, с. 253-254; ВідВРУ, 20.04.1993, № 16, с. 431) = Відомості Верховної Ради України. Нормативний бюлетень. Офіційне видання. Київ: Парламентське видавництво.

ЕСУМ = Мельничук, О. (ред.). (1982-2012). Етимологічний словник украйнської мови (Т. 1-6). Київ: Наукова думка.

Крип'я кевич, I. (2009). Історичні проходи по Львові. Львів: Апріорі.

Лав риненко, А. (2008). Польское языковое влияние в староукраинской деловой письменности $X I V-X V$ веков. Rzeszów: Wydawnictwo UR.

Осташ, Р. (2007). До питання про онімізацію апелятивів при виникненні ойконімів у XVIXVII cm. (Випуск 1 (16)). В: Наукові записки Тернопільського національного педагогічного університету. Серія: Мовознавство [сс. 222-235]. Тернопіль: ТНПУ. 
Срезн. = Срезневский, И. И. (ред.). (1893-1903). Материалы для словаря древнерусского языка по письменным источникам (Т. 1-3). Санкт-Петербург: Издание Отделения русского языка и словесности Императорской академии наук.

ССУМ = Гумецька, Л. (ред.). (1977-1978). Словник староукрайнської мови XIV-XV cm. (Т. 1-2). Київ: Наукова думка.

Старчевский = Старчевскій А.В. (ред.). (1899). Словарь древн\#го слав\#нскаго \#зыка (составленный по Остромирову Евангелію. Ф. Миклошичу, А.Х. Востокову, Я.И. Бередникову и І.С. Кочетову). СПб: Изданіе А.С.Суворина.

СУМ = Білодід, І. (ред.). (1970-1980) Словник украӥнської мови (Т. 1-11). Київ: Наукова думка. СУМ XVI = п. пол. XVII ст. - Гринчишин Д. (ред.). (1994-2004). Словник української мови XVIпершої пол. XVII cm. (Випуск 1-11). Львів: Інститут українознавства імені І. Крип’якевича НАН України.

Тимченко = Тимченко, С. (ред.). (1930). Історичний словник украйнського язика (Т. 1. А- Ж). Харків-Київ: Державне видавництво України.

ЦДІАЛ (Фонд 52, опис 1, справа 391, аркуш 26-27) = Центральний державний історичний архів у місті Львові.

\section{SUMMARY}

\section{RELICS OF THE APPELLATIVE *VOLJA IN MODERN UKRAINIAN AND POLISH OIKONYMIC SPACE}

The productiveness and localization of modern place names with the component *volja that underwent further onymization in the $15^{\text {th }}$ to $16^{\text {th }}$ centuries was authenticated in the article. It signifies a new type of newly coined localities in Polish and Ukrainian oikonymy designating settlements that were free from taxes, in particular, Polish (Wola, Wolica, Wólka), Ukrainian (Воля (Volia), Волиия (Volytsia), Волька (Vol'ka)) and their derivatives. Polish and Ukrainian oikonyms with the components Wola $\sim$ Воля (Volia) over the period of history of their use formed homogeneous structural types that are used today: single-word oikonyms, multiword oikonyms with pre- and postpositional adjectival components, and pre- and postpositional component -воля (-volia)/-волиця (-volytsia), multiword onyms: 1) Adj. + Subst. Wola, Wolica, Wólka Воля (Volia), Волиия (Volytsia), Волька (Vol'ka); 2. Subst. Wola, Wolica, Wólka Воля (Volia), Волиия (Volytsia), Волька (Vol'ka) + Adj. From the point of view of signification, these oikonyms denote a type of a free settlement indicating their owner or founder, geographical location, location in relation to neighbouring settlements, i.e. the differentiating and localising function of these types of onyms is emphasized. The number and geographical distributions of the oikonyms in Poland and Ukraine are presented. It was established that their highest number is in Lublin, Małopolskie, Podkarpackie and Mazowieckie Voivodeships (Poland) and in the west of Ukraine (Lviv, Volyn, Ternopil Oblasts). The naming tendencies of the further onymization of the appellative *volja in Ukrainian and Polish oikonymy were emphasized.

Keywords: appellatives (Ukrainian воля (volia), воличя (volytsia), волька (volka); Polish wola, wolica, wólka); onymization of appellatives, oikonymy, structural types of oikonyms 


\section{REFERENCES}

AGZ — Tatomir, L., Liske, K. i Prochaska, A. (Eds.). (1868-1935). Akta grodzkie i ziemskie czasów Rzeczypospolitej Polskiej z Archiwum tak zwanego Bernardyńskiego we Lwowie [Town and land acts of Rzeczpospolita from so called Bernardyński Archive in Lwów] (Vols. 1-25). Lwów: w drukarni Zakładu im. Ossolińskich.

AP 2021 = Alfavìtnij pokažčik naselenih punktìv Ukraïni [Alphabetical Index of Place Names of Ukraine]. http://static.rada.gov.ua/zakon/new/NEWSAIT/ADM/zmist.html (accessed: 21-27.02.2021).

Atl. Jabł. = Jabłonowski, A. (Ed.). (1889-1904). Atlas historyczny Rzeczypospolitej Polskiej. Epoka przełomu z wieku XVI na XVII. Part II: Ziemie ruskie Rzeczypospolitej [Historical Atlas of Rzeczpospolita at the Turn of Sixteenth and Seventeenth Centuries. Part 2: Rus Lands of Rzeczpospolita]. Warszawa-Wiedeń: C. i K. Wojskowo-Geograficzny Zakład w Wiedniu.

ATU 2021 = Skopnenko, G.P. (Ed.). (2012). Ukrä̈na: Administrativno-teritorial'nij ustrìj (stanom na 1 sična 2012) [Ukraine: Administrative Territorial Division (as of 1 January 2012)]. Kiev: Parlaments'ke vidavnictvo.

AÛZR (1859-1914) = Arhiv Ûgo-Zapadnoj Rossii, izdavaemyj Vremennoû komissiê̂ dlâ razbora drevnih aktov vysočajše učreždennô̂ pri Kievskom, Podol'skom i Volynskom general-gubernatore [Archive of South Western Russia Published by Temporary Board for Interpreting Ancient Acts Founded at Kiev, Podolskyi and Volynskyi General Governor]. (pp. 1-8, t. 1-35). Kiev: $\mathrm{V}^{\prime \prime}$ universitetskoj tipografiì.

Bijak, U. (2021). Space and landscape in Polish toponymy. Jazykovedný časopis (Journal of Linguistics), 72(1), 194-207.

Boryś, W. (2005). Stownik etymologiczny języka polskiego [Etymological Dictionary of the Polish Language]. Kraków: Wydawnictwo Literackie.

CDÌAL (Fond 52, opis 1, sprava 391, arkuš 26-27) = Central'nij deržavnij ìstoričnij arhìv u mìstì L'vovì [Central State Historical Archives of Ukraine in Lviv. Fund № 52. Volume number 1. Case 391, Page number 26-27].

Czapla, A. (2011). Nazwy miejscowości historycznej ziemi lwowskiej [Place Names of the Historical Lwów Land]. Lublin: Towarzystwo Naukowe KUL.

Czapla, A. (2018). Nazwy miejscowości historycznej ziemi halickiej [Place Names of the Historical Halicz Land]. Lublin: Wydawnictwo KUL.

Czopek-Kopciuch, B. (1988). Nazwy miejscowe dawnej ziemi chetmskiej i betskiej (w granicach dzisiejszego państwa polskiego) [Place Names of the Former Chełm and Bełz Lands (within the Borders of Today's Polish State)]. Wrocław: Zakład Narodowy im. Ossolińskich.

Dąbkowski, P. (1939). Podział administracyjny województwa Ruskiego i Bełskiego w XV wieku (z mapa) [Administrative Division of Ruthenian and Belzke Voivodeship in the $15^{\text {th }}$ century (with map)]. W: Zabytki dziejowe [Historical Monuments] (Vol. 5). Lwów: Towarzystwo Naukowe.

ESI = Gloger, Z. (1903). Encyklopedia staropolska ilustrowana [Old Polish Illustrated Encyclopedia] (Vol. 4). Warszawa: druk P. Laskauera i W. Babickiego.

ESUM = Mel'ničuk, O. (Ed.). (1982-2012). Etimologičnij slovnik ukraïns 'koï movi [Etymological Dictionary of the Ukrainian Language] (Vols. 1-6). Kiïv: Naukova dumka.

Krajč ovič, R. (2005). Živé kroniky slovenských dejín skryté v názvoch obcí a miest [Live Chronicles of Slovak History, Hidden in the Names of Villages and Towns]. Bratislava: Literárne informačné centrum.

Krip'âkevič, İ. (2009). İstoričnì prohodi po L'vovì [Historical Transitions in Lviv]. L'vìv: Aprìorì. Lavrinenko, A. (2008). Pol'skoe âzykovoe vliânie v staroukrainskoj delovoj pis'mennosti XIV$X V$ vekov [Polish Linguistic Influence on the Old Ukrainian Business Writing in the $14^{\text {th }}$ and $15^{\text {th }}$ Centuries]. Rzeszów: Wydawnictwo UR. 
Lustr. 1661-1665/II = Arłamowscy, E. i K. (Eds.). (1974). Lustracja województwa ruskiego 16611665. Cz. II. Ziemia Lwowska [Lustration of the Ruthenian Voivodeship 1661-1665. Part 2. Lwów Land]. Wrocław: Zakład Narodowy im. Ossolińskich.

MRPS = Wierzbowski T. (red.). (1905-1910). Matricularum Regni Poloniae Summaria (Vols. 1-4). Varsoviae: Typis officinae C. Kowalewski.

NMPol = Rymut, K. et al. (Eds.). (1996-2018). Nazwy miejscowe Polski. Historia. Pochodzenie. Zmiany [Place Names of Poland. History. Origin. Changes] (Vols. 1-15). Kraków: Instytut Języka Polskiego PAN-DWN..

Ostaš, R. (2007). Do pitannâ pro onìmìzacîu apelâtivìv pri viniknennì ojkonìmìv u XVI-XVII st. [To the question of onimization of appellatives in the formation of oikonyms in $16^{\text {th }}-17^{\text {th }}$ centuries]. Naukovì Zapiski Ternopil's'kogo nacional'nogo pedagogičnogo unìversitetu. Serîa. Movoznavstvo, 1(16), 222-235.

Pluskota, T. (1998). Nazwy miejscowe ziem ruskich Rzeczypospolitej XVI-XVIII w. [Place Names of Ruthenian Territories of the Polish Republic in the $16^{\text {th }}-18^{\text {th }}$ Centuries]. Bydgoszcz: Wydawnictwo Uczelniane WSP w Bydgoszczy.

SG = Sulimierski T. et al. (Eds.). (1880-1902). Stownik geograficzny Królestwa Polskiego i innych krajów stowiańskich [Geographical Dictionary of the Kingdom of Poland and Other Slavic Countries] (Vols. 1-15). Warszawa: nakładem Filipa Sulimierskiego i Władysława Walewskiego. Druk ,Wieku”.

Srezn. = Sreznevskij I.I. (Ed.). (1893-1903). Materialy dlâ slovarâ drevnerusskogo âzyka po pis'mennym istočnikam [Materials for the Dictionary of Old Russian] (Vols. 1-3). SanktPeterburg: Izdanie Otdeleniâ russkogo âzyka i slovesnosti Imperatorskoj akademii nauk.

SSUM = Gumec'ka, L. (1977-1978). Slovnik staroukraïns'koï movi XIV-XV st. [Dictionary of the Old Ukrainian Language in the $14^{\text {th }}-15^{\text {th }}$ Centuries] (Vols. 1-2). Kiïv: Naukova dumka.

Starčevskij = Starčevskij, A. V. (Ed.). (1899). Slovar' drevnego slavânskago âzyka (sostavlennyj po Ostromirovu Evangeliû) [Dictionary of the Old Slovenian Language (compiled on the basis of Ostromyrove Evanheliye)]. SPB: Izdanì A.S. Suvorina.

SUM = Bìlodìd, İ. (Ed.). (1970-1980). Slovnik ukrä̈ns 'kö̈ movi [Dictionary of the Ukrainian Language] (Vols. 1-11). Kiïv: Naukova dumka.

SUM XVI-p. pol. XVII st. = Grinčišin D. (Ed.). (1970-1980). Slovnik ukraïns'koï movi XVI-peršoï pol. XVII st. [Dictionary of the Ukrainian Language $16^{\text {th }}$-First Half of $17^{\text {th }}$ Centuries] (Vols. 1-11). L'vìv: İnstitut ukraïnoznavstva ìmenì İ. Krip âkeviča NAN UKRAÏNI.

Surma, G. (1996). Nazwy miejscowe z członem Wola, Wólka, Wolica w procesie komunikacji językowej (na przykładzie Opoczyńskiego) [Oikonyms with Volia, Vólka, Volica components in the process of language communication (exemplified by Opoczno Region))]. Onomastica, 41, 51-56.

SW = Karłowicz J. et al. (Eds.). (1900-1927). Stownik języka polskiego [Dictionary of Polish] (Vols. 1-8). Warszawa: nakładem prenumeratorów w drukarni E. Lubowskiego i S-ki.

Timčenko, Ê. (1930). İstoričnij slovnik ukrä̈ns'kogo âzika [Historical Dictionary of the Ukrainian Language] (Vol. 1: A-Ž). Harkìv-Kiïv: Deržavne vidavnictvo Ukraïni.

VidVRU (03.03.1992, №9, p. 251; 03.03.1992, №9, pp. 253-254; 20.04.1993, №16, p. 431)= Vìdomostì Verhovnoï Radi Ukraïni. Normativnij bûleten' [Supreme Council Bulletin]. Oficijnevidannâ. Kiïv: Parlaments'ke vidavnictvo.

Wykaz (2019) = Wykaz urzędowych nazw miejscowości i ich części [List of Official Names of Localities and Their Parts (2019)]. http://ksng.gugik.gov.pl/urzedowe_nazwy_miejscowosci.php (accessed 21-25.02.2021). 